\title{
Business Communication Needs of Japanese Companies in Malaysia
}

\author{
Yeoh Lee Su (Corresponding author) \\ Universiti Sains Malaysia, Malaysia \\ E-mail: 1syeoh@usm.my \\ Tengku Sepora Tengku Mahadi \\ Universiti Sains Malaysia, Malaysia \\ Manjet Kaur Mehar Singh \\ Universiti Sains Malaysia, Malaysia
}

Doi:10.7575/aiac.alls.v.7n.2p.156

Received: 28/11/2015

URL: http://dx.doi.org/10.7575/aiac.alls.v.7n.2p.156

Accepted: 23/01/2016

\begin{abstract}
Business relationship between Japan and Malaysia has developed very quickly in recent years. This has caused a dramatic increase in the need for individuals who possess language skills to function in Japanese businesses. In order to investigate the needs of our Malaysian graduates, a survey was conducted involving graduates of Japanese language minor program from a public university in Malaysia. The aims of the survey were to get an overall understanding of (1) the use of Japanese language at workplace where the Japanese language minor program's graduates are employed; (2) identify problems faced in language use and in terms of Japanese business practices in workplace. The results indicated that the graduates use Japanese language to communicate with the employees of their workplace compared to outsiders. The findings also highlight that Japanese language listening and speaking skills are the most important skills needed by the graduates for their workplace success compared to reading and writing.
\end{abstract}

Keyword: Japanese Companies, Business Japanese, Japanese Business Practices

\section{Introduction}

Globalization of Japan's industry rapidly escalated in the late 1980's because of competition in the international market and international trade policies. With quick development of the Japanese economy, individuals in numerous nations experienced expanded chances to work together or work with the Japanese. Malaysia is not an exception. Japanese's direct foreign investment (DFI) was a key to achieving in the succession economic growth of Malaysia's New Economic Policy (NEP) (1971-1990) (Wendy \& Smith, 1994). In the 1970s, the quantity of Japanese subsidiaries and joint ventures in Malaysia expanded fundamentally (Imaoka, 1985). By 1979, about $43 \%$ of Japanese joint ventures in Malaysia were occupied with assembling, essentially in the hardware, wood items, and chemicals (Smith \& Wendy, 1994; Wendy \& Smith, 1994).

Japan has been Malaysia's principle exchange associate and in addition a noteworthy supplier of remote direct speculation and financial help (Furuoka, 2002). Respective relations between the two nations were further strengthened through the "Look East" strategy presented by Malaysian Prime Minister Tun Dr. Mahatir bin Mohamad in the beginning of the 1980s. Since the presentation of the "Look East" policy two decades earlier, economic and diplomatic relations as well as cultural exchanges between Malaysia and Japan have flourished.

Todays, more Japanese organizations are deciding to put resources into Malaysia as they are pulled in by the nation's five "plus-points". "The plus-points were the growing economy, political stability, free from natural disaster, good infrastructure such as water, electricity and gas supplies, as well as an English-speaking workforce", said Japanese Ambassador to Malaysia Shigeru Nakamura to The Star newspaper on $20^{\text {th }}$ January 2012. This is very important in creating more jobs and, subsequently, economic growth. Besides that, according to The Japan Times on 14 August 2012, increasing quantities of Japanese organizations have moved some of their base camp or key functions to Singapore, seeing the city-state as a key area where they can regulate another rush of interest in Southeast Asia especially in neighboring Malaysia. Spectators say the pattern quickened after the catastrophic earthquake and tsunami that hit Japan in March 2011 and awakened the Japanese organizations to the need to expand their operations to lessen future dangers (Rahil, 2012). 
Nowadays, numerous countries have felt the need to educate graduates who are multilingual and multicultural in the push to compete in the worldwide society. In an undeniably reliant world, learning of foreign languages is seen not just as an included point of preference which has gotten to be vital in accessing foreign technology but also is systematically associated with one's meaningful and constructive engagement in politics, security, worldwide exchange and education. So, to engage in the worldwide economy, one must be satisfactorily furnished with the target language, capacity, information, abilities, and dispositions to comprehend. Malaysia has recognized the significance of skill in foreign language with a specific end goal to create human capital that drives the national economy in the worldwide enclosure.

As a multi-racial nation, Malaysia is also influenced by the worldwide industrialization pattern. Employment situation in Malaysia necessitates the need for graduates to gain employable aptitudes incorporating skill in a foreign language and foreign companies' business knowledge. Globalization since 1990s constrained Malaysia's pioneers to hold onto globalization as a force that would allow Malaysia to be integrated into the rest of the world and boost its national economy (Omar, 1982). Reliably, in education sector, educational leaders have been stressing the need to encourage foreign language competency among students (Zeszotarski, 2001; Welles, 2004; Christian et al., 2005; Ainol et al., 2007).

Business relationship between Japan and Malaysia having developed very quickly in recent years, has caused a significant uptrend in the need for individuals who possess language skills in business Japanese and who are knowledgeable with Japanese business practices. In order to fulfill the business communication needs of Japanese companies in Malaysia and also to be able to respond to the employment of Japanese language learners, there is a need to improve the curriculum of Japanese language minor programs and Japanese as a foreign language in Malaysian higher education institutions.

In 2002, a survey (Yeoh, n.d.) was conducted to investigate the needs and opinions from the graduates who took the Japanese language as their minor program at Universiti Sains Malaysia (USM). The curriculum of the conventional Japanese minor program is an integrated Japanese language course divided into level 1 to 5 . The results of the investigation showed that the graduates strongly seek business Japanese language; thus, the curriculum of Japanese minor program's final level was changed to business Japanese language.

To further investigate whether the new business Japanese language curriculum is beneficial to the graduates in their workplace, another survey was carried out by Yeoh (2015). The aims of the survey were to get an overall understanding of (1) the use of Japanese language at workplace where the Japanese language minor program's graduates are employed; (2) identify problems faced in language use and in terms of Japanese business practices in workplace.

\section{Rationale of the Study}

The quantity of Japanese subsidiaries or joint-ventures in Malaysia has altogether expanded. One of the reasons is business in Japan is declining particularly due to the decreasing and aging population. Japanese companies in Japan are under pressure to make the transformation into globally focused companies (Izumi, Ito \& Ishihara, 2014). This has led many Japanese businesses to invest and start their operations in other countries especially Southeast Asian countries. Therefore, in new off-shore business in South East Asian, there is a dire need for capable local university graduates in terms of Japanese language and Japanese business knowledge for their businesses. As the result, more and more Japanese companies are approaching university graduates particularly in ASEAN countries to search for excellent new graduates (Izumu, Ito \& Ishihara, 2014). Due to the reason mentioned above and as the result of globalization, workplace is more diversified in Malaysia. In 2014 April, the presence of Japanese companies in Malaysia, be it joint venture or wholly-owned by Japanese (termed Japanese Related Companies in Malaysia, JRCM) total 1412 companies (JETRO 2014). Malaysia is the second biggest host to Japanese companies in Southeast Asia after Thailand. Due to the increasing importance of international commerce to Malaysia's economy, the concept of Japanese language and Japanese business knowledge has become a vital element to the success of Japanese Related Companies in Malaysia (JRCM) (ASCOJA 2013).

Japanese employers and Malaysian employees work together and communicate with each other within these organizations. Organizational Communication is more complex than that in homogeneous organizations and cultural diversity is considered potentially problematic (Shuter \& Wiseman, 1994). This is due to heterogeneous workplaces are more risky than homogeneous ones because differences often become sources of conflicts, misunderstanding and poor performance (Salk \& Brannen,2000). Communication abilities are considered important in the Japanese subsidiaries or joint-ventures in Malaysia. Successful communication is crucial to the functioning of any organization. Information must be conveyed, received, understood and acted upon in a proper manner in order to maintain an organizational efficiency. In the diversity of the nature of business of multinational companies, Malaysians have to deal with foreign managers, employees, suppliers, customers, distributors in Japanese companies, whose social and communicative backgrounds differ significantly from theirs.

Leaders in many professions now realize that fluency in a foreign language especially Japanese and multicultural sensitivity are essential in their fields if the Malaysia is to participate effectively in this global community. For these reasons, Malaysia needs to train many more professionals who can communicate effectively with foreigners and who are sensitive to cultural differences. Knowledge of foreign languages and familiarity with foreign companies' business knowledge are a key to success (Ainol et al., 2007). 
As indicated by the National Higher Education Strategic Plan Beyond 2020 (The Ministry of Higher Education, 2007), "Proficiency in the third language is vital for developing human capital that drives the k-economy as well as gears the country towards competitive innovation in the international arena," (p.62). Malaysian universities are supported "to provide learning opportunities for students to be proficient in a third language such as Mandarin, Tamil, Japanese, French or Spanish," (p.66). Besides, the third language will allow graduates not just to become acquainted with the most recent innovation and data, additionally to get an added advantage in an increasingly multicultural and diverse work environment where more opportunities are opened to a workforce that is competent in several languages. The significance of foreign languages in a borderless world is more apparent when nation building is very dependent on the acquisition and transfer of foreign technology. In perspective of the expanding expectations for graduates to be proficient about a foreign language there is a need to conduct more research in this area particularly concerning what are the needs and requirement of the workplace.

As of late, calls have been made for graduates to be capable in oral relational abilities with the goal that they can work adequately in the working environment. Oral communication covers a wide zone, going from formal presentation to participation in teams and meetings. The literature indicates obviously that oral communication is an imperative part of the working environment, and that Japanese speaking graduate employees require effective skills in this domain if they are to be fruitful in their Japanese business environment. In workplace with personnel of distinctive ages, sexes and national, social, and ethnic foundation, it is clear that, as employees' communication is shaped by differing cultural values and norms, the outcome will be variation in preferred modes of interaction. Japanese speaking graduate employees would need to be furnished with an understanding of these distinctions in order to navigate difficulties that may arise. Remotely, the undeniably globalized nature of the business world effects on correspondence forms. With numerous associations now opening crosswise over national limits, the requirement for workers to have culturally diverse comprehension is underscored (Liu \& Beamer, 1997).

To abridge, oral communication is as essential to and as effective in the working environment as it is in the societal existence of people. Being context-dependent it is formed by component's external and internal environments. Besides, fruitful correspondence relies upon the gatherings, sharing foundation information and presumptions, and miscommunication can come about if there is a mismatch in the speakers' intent. Above all, Malaysian with Japanese language competence and Japanese business knowledge are in high demand in Japan Related Companies in Malaysia (JRCM). Cultivating students' Japanese language competence and Japanese business knowledge, therefore, has become a major requirement for Japanese language education in South East Asian universities (Izumi, Ito \& Ishihara, 2014).

\section{Related Literature Reviews}

Currently, due to the activation of Japanese companies expanding in the Asia region, demand for individuals who possess Japanese language skills to function in Japanese businesses is increasing (Yoshikawa 2002). However, there is insufficient investigation about level of Japanese required in the actual business activities. In addition, teaching materials and teaching methods of business Japanese at overseas higher education institutions also have not been progressively developed. At present, the institutions in foreign countries especially in ASEAN are using text and video teaching materials that are designed merely for the situation of Japan (Harada 2004).

Studies have revealed on the problems faced by foreign business people in conducting business activities with the Japanese in Japan (Shimuzu, 1995 \& Kondo, 1998). According to Shimuzu (1995), foreign business people who possess the advance Japanese language proficiency pointed that "express an opinion" is particular problem faced. In Kondo's investigation (1998), "unfair treatment", "non-efficiency of work", "differences of work practices ", and "difference of cultural habit" were the problems mentioned by the foreign business people. In addition, Nishio's study (1995) showed the characteristic of the Japanese language education needed by the foreign business people who worked in Japan were diversification, efficiency, understanding of business communications, including business practices and honorific. These research in the Japan business scene is mostly intended for advanced Japanese language learners, but most of the Japanese language learners in foreign countries are at the beginner or intermediate levels. How these learners acquired the Japanese language and what are the problems they faced in foreign countries have not been investigated widely.

Chin Prasat Suk (2005) conducted a research on business communication problem between the Japanese and Thais local business people. The findings showed that the feedback from Japanese and the Thais are roughly the same for the three factors, there are "interpretation ability," "mutual understanding of communication", "time management". Case study by Miyazoe (1997 \& 2003) in the multi-language workplace in Hong Kong and the use of Japanese language survey of overseas business scene by Shimada and Shibukawa (1999), investigating Japanese companies of five Asian cities including Kuala Lumpur, showed that the Japanese companies had high expectations of the business communication toward the foreign Japanese speakers. However, focus of the surveys were more in the usage of Japanese language in business situation and not focused in Japanese business practices and culture.

Since the existence and Japanese use in the Japanese related companies in oversea is different from the organization in Japan, the problems that occur in Japanese related companies in overseas is difference from the organization in Japan. The literature review showed that there are researches done among foreign business people in Asean countries. However, the research done in Malaysia is very minimal. Furthermore, in previous studies on the Japanese use among foreign business people, Malaysia workplace business Japanese language use was not mentioned. Therefore, there is a need to conduct the research that focus on Japanese related companies in Malaysia. 


\section{The study}

\subsection{Objectives}

This research purpose is to find out the actual situation these graduates are facing.

A survey was conducted to investigate

1) How Japanese is used in the workplace of the Japanese language minor program's graduates?2) What kind of problems are faced in language use by the Japanese language minor program's graduates?

3) What are the problem faced by the Japanese language minor program's graduates in terms of Japanese business practices?

\subsection{Survey Method}

The questionnaire was designed with the framework used by Shimada and Shibuya (1999) and Wendy Tiong (2010). The investigation was conducted through survey quantitative and qualitative with the graduates. The questionnaire consists of both close-ended and open-ended questions. The quantitative data, close-ended questions were to grasp the overview of the use of the Japanese language. The qualitative data, open-ended questions were to collect data regarding the problems faced by the graduates in the Japanese language use at the workplace and the problems faced by the Japanese language minor program's graduates in terms of Japanese business culture at workplaces. Both of the questionnaire were in English.

\subsection{Sample}

Thirty sets of questionnaires were sent out to the Japanese language minor program's graduates who are working for Japanese related companies in Malaysia, be it joint venture or wholly-owned by Japanese (termed Japanese Related Companies in Malaysia, JRCM) and twenty one sets were returned. Though the numbers of the sample were small but the questionnaires returned were completely answered.

5.4 Survey period

The questionnaire survey was from May 2015 to November 2015.

\section{Finding and Discussion}

\subsection{Participants}

The participants of the survey were 21 of the Japanese language minor program's graduates who are working for JRCM and using Japanese for business purposes. They were 30 to 33 years old. Two (9.5\%) participants have passed Japanese Language Proficiency Test (JLPT) N1, five (23.8\%) of them have passed N2 and 14 of them have passed N3 (66.7\%). The industries the companies belong to is manufacturing.

\subsection{Data analysis}

Quantitative data analysis involved descriptive statistics. The qualitative data from the questionnaire was manually analyzed by the researcher.

\subsection{Findings}

Japanese used at workplaces - Quantitative Findings

Table 1. Speak or Listen to Japanese

\begin{tabular}{ll}
\hline Purpose & $\%$ \\
\hline Greetings & 91 \\
\hline Casual conversation with Japanese colleagues & 74 \\
\hline Work conversation with Japanese colleagues & 65 \\
\hline Interpretations for simple casual conversation & 52 \\
\hline Participating in meeting & 29 \\
\hline
\end{tabular}

Table 2. Reading

\begin{tabular}{ll}
\hline Purpose & $\%$ \\
\hline Reading office e-mails & 92 \\
\hline Reading office memos & 61 \\
\hline Reading business reports and letters & 56
\end{tabular}


Table 3. Writing

\begin{tabular}{ll}
\hline Purpose & $\%$ \\
\hline Writing office e-mails & 57 \\
\hline Reading office memos & 30 \\
\hline Reading business reports and letters & 28 \\
\hline
\end{tabular}

Table 1, 2 and 3 are the findings of the Japanese language used at workplaces in JRCM. For speaking or listening to Japanese, the most important use was 'Greetings' (91\%), the second was 'Casual conversation with Japanese colleagues' (74\%), the third was 'Work conversation with Japanese colleagues' (65\%) and the fourth was 'Interpretations for simple casual conversation' (52\%) and last was participating in meeting (29\%). The findings show that the use of Japanese by the graduates are more with their colleagues rather than outsiders such as their clients or business partners.

The results also show that the graduates are involved in 'interpretations for simple casual conversation'. This implies that the graduates play the role to connect Japanese speakers and non-Japanese speakers the JRCM. For reading, the most popular purpose was 'reading office e-mail' (92\%), second was 'reading office memo' (61\%) and followed by 'reading business reports and letters' (56\%). Table 2 and table 3 show that the opportunity for writing was followed by the same sequence as reading. However, for 'reading office e-mail' was $92 \%$ while only $57 \%$ for 'writing office email'. This is because reading skills of the graduates are better than their writing skills. Furthermore, this result shows that the reading ability is more important than writing ability for the graduates.

a) Problems faced in language use at workplaces - Qualitative Findings

The qualitative data involving open-ended questions were used to collect data regarding the problems faced by the graduates in the Japanese language use at the workplace. Seven (33.3\%) graduates responded that they faced problems in using Japanese language at work in the open-ended question. Seven of them have obtained JLPT N1 and N2, while those responded "No" to the question "Did you encounter any problems in using Japanese language at work?" were those who obtained N3 in JLPT test (14 of the graduates , 66.7\%). The results show that the graduates with a higher level of proficiency in Japanese language faced more problems compared to graduates with lower level of Japanese language proficiency. Out of seven of the graduates who obtained JLPT N1 and N2, six of them responded in the closeended questionnaire that in their job, speaking is the most important skill that requires them to have Japanese language proficiency in. Furthermore, they are those involved in participating in meetings. This may imply that the graduates with the higher Japanese language proficiency handle more difficult tasks compared to the graduates with the lower of Japanese language proficiency and as a result they faced more problems in language use at workplaces.

The open-ended questions also requested the graduates to describe the kind of problems they faced in using Japanese at work. The most frequently occurring response was business expression and business vocabulary, followed by honorific expression, technical terms and worried that an inappropriate words is used during conversation.

i) Business expression and business vocabulary

ii) Honorific expression

iii) Technical terms

iv) Worried that an inappropriate word is used during conversation

The graduates describe that the main problem they faced is expressing themselves in workplace because business expression and honorific expression in Japanese are very difficult for them as foreigners and this make them worry that they might inappropriately use them.

b) The problem faced by the Japanese language minor program's graduates in terms of Japanese business practices at workplaces - Qualitative Findings

The qualitative data involving open-ended questions were used to collect data regarding problems faced by the Japanese language minor program's graduates in terms of Japanese business practices at workplaces. The most common problems the graduates expressed were difficulties with different working culture and the Japanese ways of expressing ideas.

i) Different working culture.

ii) Japanese way of expressing ideas

The graduates commented that the different working culture and the Japanese way of thinking and behaviors were the most difficult problems they faced in workplace because Japanese tend to hide their real thoughts and feelings. Furthermore, they faced the difficulties in communication and clear conclusion of business discussion in the workplace because problem solving and decision making are processes that the Japanese take a long period of time to complete.

\section{Discussion}

The results indicated that the graduates used Japanese language to communicate with the employees of their workplace compared to outsiders. The findings also highlight that Japanese language listening and speaking skills are the most 
important skills needed by the graduates for their workplace success compared to reading and writing. (Table 1,2 and 3).

However, for 'reading office e-mail' was $92 \%$ while only $57 \%$ for 'writing office e-mail'. This is because reading skills of the graduates are better than their writing skills. Furthermore, this result shows that the reading ability is more important than writing ability for the graduates. The graduates describe that the main problems they faced in Japanese used is to express themselves in workplace because business expression and honorific expression in Japanese are very difficult for them as foreigner and this make them worry that they might inappropriately use it. However, the problems faced by the Japanese language minor program's graduates in terms of Japanese business practices at workplaces were the difficulties in communication and provision of clear conclusion of business discussion in the workplace. This was due to different working culture and the Japanese way of expressing ideas indirectly. This study also provided an interesting results that the graduates with a higher level of proficiency in Japanese language faced more problems compared to graduates with lower level of Japanese language proficiency in their workplace.

\section{Conclusion}

This paper provides a guidelines for the Japanese language teachers in teaching implication and the information regarding the competencies needed for the graduates to able them to work successfully in Japanese related companies in Malaysia. Furthermore, the study provides guidelines for the new graduates who are interested in working in Japanese related companies in Malaysia that they must prepare to cope with the problems they may have in working with Japanese employers. It is hoped that information presented in this paper will be beneficial for the graduates to perceive and learn the language and the Japanese business practices.

\section{References}

Omar. A.H. (1982). Language and Society in Malaysia. Kementerian Pelajaran Malaysia. Kuala Lumpur: Dewan Bahasa dan Pustaka: Kuala Lumpur.

Zubairi, A.M., Sarudin, I. H., \& Nordin, M. S. (2007). A Study of the effectiveness of Foreign Language Programs in Malaysia. Proceedings in the 32nd Annual Congress of the Applied Linguistics Association of Australia, Making a Difference: Challenges for Applied Linguistics, University of Wollongong, 1-3 July, 2007.

Brannen, M.Y., Salk, J.E. (2000). Partnening Across Borders: Negotiating Organizational Culture in a GermanJapanese Joint Venture. Human Relations, 53(4), 451-487.

Carnevale, A.P., Gainer L.J., Meltzer A.S. (1990). Workplace basics: The essential skills employers want. San Francisco: Jossey-Bass Publishers.

Chee, M.C. (2001). An Investigation into the Needs of Business Japanese of the University, Graduates and Local Business Communication in Hong Kong. The Journal of Japanese Language, 5, 31-42.

Christian, P., \& Rhodes, N. (2005). Fostering foreign language proficiency: What the US can learn from other nations, Phi Delta Kappan, 87(3), 226-228.

Furuoka, F. (2002). Economic Relations Between Malaysia And Japan: Investment, Trade And Economic Assistance 1. Institute for Development Studies, 13(2), 130-147.

Halliday, M.K.(1978). Language as social semiotic. London: Edward Arnold.

Imaoka, H. (1985). Japanese management in Malaysia. Southeast Asian Studies 22(4), 339-356.

Izumi, W., Ito, A., \& Ishihara, E. (2014). What are the Problem with Business Japanese Competencies? A Study Based on Surveys of Business People Working in Japan-Related Workplace. Proceedings of CLaSIC 2014.

Japan Foundation (2011). Objective and Histrory. Retrieved June 20, 2011.

JATRO (2011), Japan External Trade Organization. Retrieved from http://www.jetro.go.jp/

Liu, D., Beamer, L.(1997) Multimedia as a teaching Tool in Business Communication Course Delivery. Business Communication Quarterly, 60(2), 51-66.

Mellinger, W.M. (1992). Talk-as-work: the case of paramedic calls for emergency field orders. Current Research on Occupations and Professions, 7, 79-109.

Muguda,Y.（2007）「ビジネス・コミュニケーションを中心とした中級向けのシラバス開発一日印ビジネス 現場における日本語使用実態調査をもとに一『日本言語文化研究会論集』第3号, 国際交流基金日本語国際 センター・国立国語研究所政策研究大学院大学, 197-224.

Ooi, C.K. (2013). ASCOJA towards the Cooperation and Development of ASEAN+Japan. Proceedings in the The $20^{\text {th }}$ ASEAN Council of Japan Alumni (ASCOJA) Conference, ASCOJA Towards the Cooperation and Development of ASEAN \& Japan, The International Conference Center (ICC), Hanoi, 6-8 September, 2013.

Rahil, S. (2012, August 14). More Japanese firms relocating to Singapore. The Japan Times. Retrieved from http://www.japantimes.co.jp

Shimada, M., \& Shibukawa, S. (1999). Japanese language usage in Japanese companies in five Asian cities. Journal of Japanese Language Teaching, 103, 109-118. 
Shuter, R., Wiseman,R. L. (1994). Communication in multinational organizations: conceptual, theoretical and practical issues. CA: Sage Thousand Oaks.

Smith, Wendy, A. (1994). A Japanese Factory in Malaysia: Ethnicity as a management ideology. In Sundaram, Jomo Kwame (Eds.), Japan and Malaysian development: in the shadow of the rising sun,154-181. Routledge.

The Ministry of Higher Education. (2007). The National Higher Education Strategic Plan beyond 2020. The Ministry of Higher Education Malaysia Press.

Welles, E. B. (2004). Foreign language enrollments in United States institutions of higher education, Fall 2004. $A D F L$ Bulletin, 35, 73-95.

Yeoh, L. S. (2011) 「マレーシアにおける日系企業で使われるビジネス日本語に関するニーズ調＼cjkstart査」『異 文化コミュニケーションのための日本語教育』1、高等教育出版社、1004-1005.

Yeoh, L. S. (2011). Business Communication Needs of Japanese Companies in Malaysia: What is expected of University Graduates? Proceedings in 2011 Asian Literacy Conference in Conjunction with $7^{\text {th }}$ Litcon \& $4^{\text {th }}$ ILLC, Language \& Literacy in the Local and Global Contexts: Success Stories and Unfolding Narratives, Universiti Sains Malaysia, 11-13 October, 2011.

Yeoh, L.S., Tengku S.T.M., Manjet, K. (2015). Japanese Language and Japanese Business Knowledge Needs of Japanese Related Companies in Malaysia. Paper presented at the $6^{\text {th }}$ International Language Learning Conference 2015.

Zeszotarski, P. (2001). ERIC review: Issues in global education initiatives in the community college. Community College Review, 29, 65-72. 